\title{
THE INFLUENCE OF CHILDREN'S PLAYROOM INTERIOR ASPECT IN REGARD TO PARENTAL SAFETY PERCEPTION. CASE STUDY: CHILDREN'S PLAYROOM AT 23 PASKAL BANDUNG, INDONESIA
}

\author{
Rizka Rachmawati, Imtihan Hanom, and Santi Salayanti \\ Interior Design Study Program, School of Creative Industries, Telkom University, Indonesia \\ * Corresponding author: Rizka Rachmawati \\ Email: rizkarachmawati@gmail.com
}

\begin{abstract}
Children's playrooms in public spaces need to consider the safety of their interior elements. Previous studies also discussed about things that need to be taken into account to assure the children's safety while playing. However, some parents join their children playing in public spaces due to the cautiousness of playground safety level. This study was conducted to understand how far the interior aspects of children's playgrounds can affect parents' safety perception to let their children play by themselves in public spaces, for example, the children's playroom in 23 Paskal Bandung, West Java, Indonesia. The result shows that sufficient light, interior finishes, and noise or sound intensity in the children's playground at 23 Paskal Bandung, Indonesia can make parents feel safe to let their children spend time there.
\end{abstract}

Keywords: children's playroom, interior, safety perception

\section{INTRODUCTION}

The growth of early childhood is an important thing that needs to be considered by the community, especially parents, as there are various positive impacts gained from this growth process, making people, especially parents, want to use the best facilities for their children from an early stage. One of the facilities to support children's development is through their playroom. Today, playroom development is attracting more attention, especially for early childhood, because this period is the golden age where children experience many stimulations that will be useful for their lives later. Along with the increased attention and needs of parents to care for their children with the best facilities, various kinds of public and private institutions also pay attention to this. Therefore, they have started to build playrooms in some public areas. We can find one such playroom in a shopping centre.

Playroom is an environment that can be in direct contact with children when they are playing games in it. Children carry out continuous interactions in the room, including running, staying quiet, sitting, interacting with objects, or interacting with their playmates. Therefore, there are some things that need to be of concern for the designers when designing playrooms, such as safety, health, cleanliness, and the comfort of children when they use the playroom. Safety is needed to support the implementation of a play process that is safe for child development.

Various playrooms in public spaces have implemented good safety standards for children. However, most of these playrooms still need to be supervised by parents when the child is playing.
This is because of the age factor of the children playing in it is still classified as early childhood, whereby the involvement of parents in monitoring and playing with children is still very much needed. However, even though children are accompanied by their parents, sometimes they need to learn and play independently in exploring their environment. The parents do not need to accompany their children every time they play; sometimes, children need to be left free to recognize what is around them so that their growth process can be increased optimally. Based on this phenomenon, the safety aspect of the playroom becomes important so that parents will feel safe when allowing children to explore their environment, while still getting parental supervision. This study will discuss the extent to which the safety aspect of the playroom has been able to meet the perception of parents' security when accompanying their children to play in it.

\section{METHODS}

The methods used in this research are qualitative method (respondent questionnaire) and comparative method through comparison between questionnaire results and literature. Questionnaires were distributed to parents or guardians who accompanied their children playing in Miniapolis (Children's Playroom) in 23 Paskal Bandung. Questions set are all about assessment of interior safety aspects that should be considered in playroom and which could be perceived by parents while taking their children to the playroom. The questionnaire results are the instruments of data which were then compared to the literature. The conclusions were made as to whether the playroom is already safe based on the 
literature. Safety aspects assessed were light captured by vision, sound captured by hearing, and interior material captured through the sense of touch.

In this literature review, we will discuss the design components which comprise the safety aspect related to perceptions arising from the parent's side as a child's companion when playing. The definition of perception comes from a conventional approach, in that the five senses are the catching factors which result in the receptor experience.

\section{THE PLAYROOM'S SAFETY}

An important factor in designing a children's playroom is the aspect of interior safety, which aims to provide safety and comfort for children when playing. This component of the safety aspect is seen from the requirements for achieving a good and appropriate design in supporting children's safety while playing, including lighting, sound, healthy building conditions, safe window doors, and safe finishing materials 9 . Based on the analysis of the literature regarding the relationship between safety aspect with perceptions of safety, the influential factors are lighting (captured by the sense of vision), sound (captured by the sense of hearing), and interior material (captured by the sense of touch $)^{10}$. The following is an explanation of the safety aspect in the playroom which can affect the perception of safety.

\section{a. Lighting}

A good lighting design is needed in the playroom in order to produce the number, quality, and location points of light that can fulfill children's lighting needs when they use the room. The type of lighting itself is divided into two, namely natural lighting and artificial lighting.

Natural lighting is useful for children's health. We recommend that the playroom has a window on several sides so that natural lighting can enter the room. Natural lighting can have an effect on a child's body reaction. Research shows that color factors and light intensity can affect blood pressure, heart rate, breathing, brain activity, and metabolic functions in a child's body. The importance of natural lighting for children requires the children's playroom to receive sufficient natural light. Some of the factors which must be considered in the children's playroom for natural light to enter are the location of windows, balconies, open roofs, and the yard with the interior space position. This is intended to maximize natural light into the playroom. Measuring the effect of light sources that can reach objects and clarify colors on objects is known as the Color Rendering Index (CRI). This CRI value ranges from 1-100, and natural lighting from sunlight has a CRI value of 1009 .
In addition to natural lighting, there is also artificial lighting, which is used to illuminate areas that are not close to the window or other opening areas. The amount of CRI possessed by artificial lighting from cool white fluorescents is 62 , from warm white fluorescents is 56 , and from energy saving lamp is 48. Ideally, artificial lighting is also designed to create a light quality that is almost similar to natural lighting and can be controlled or programmed in such a way as to fit the needs of the children's activities.

\section{b. Sound}

Sound has an important role in the child growth process ${ }^{7}$. Good sound quality in the child's environment can have a good impact on the growth of children's cells, membranes, and organs. Children are very sensitive to vibrations and noise in a space, which would have an adverse effect on their growth and development. The negative effects of noise can result in hearing health problems of early childhood. Therefore, sound is one of the most important things to support the interior safety of children's playrooms. Some examples of sounds that can interfere with the children are the noise of another child crying, or the noise from foreign objects, such as a machine, vehicle, or a loud bang. This type of sound can make the children stress, and increase the unsafe perceptions. Meanwhile, friendly sounds in the ears of children, such as the voices of people talking, soft music, birdsong, and the sounds of calm nature can create comfort and calm even though they are in a new place.

\section{c. Interior Materials}

General safety requirements for interior surface materials are those that are easy to clean, antimicrobial and bacterial, and soft textured? Materials contained in interior elements include flooring, walls, ceiling and furniture. Interior material surfaces are aspects that often come into direct physical contact with the human body, in this case children and their companions. Children will receive extensive response, stimulation, and information when they interact with the surface of the material they touch. The environment can deliver messages through the surface of the interior material to get the user's response, for example, rough and hard material indicates that child should be careful in playing in that area, whereas soft material means that the area can be freely explored in the environment. Based on the differences in material types, it can be concluded that the material best suitable for the child's environment is soft and smooth.

The material type selection in a playroom should pay attention to the function of space and the activities that will be conducted in it ${ }^{7}$. The use of surface material that has this difference can provide its own experience for children. But, in choosing this different type of material, it is necessary to keep in mind the softness of the 
material to keep it safe for the child. Through the various types of textures, children can learn to recognize and interact in their environment. This certainly plays a role in the process of forming a child's character.

\section{PERCEPTION}

The Complete Dictionary of Psychology explains that perceptions are: (1) the process of knowing or recognizing objects and objective events with the help of the senses; (2) awareness of organic processes; (3) (Titchener) a sensing group with the addition of meanings derived from past experiences; (4) hinder or interfere variables, derive from the ability of the organization to distinguish between stimulants; (5) immediate intuitive awareness of the direct truth or belief about something ${ }^{4}$. Shaleh ${ }^{1}$ also explained the definition of perception actually tending to be more psychological than just a sensing process, so that there are several influence factors, such as: (a) selective attention wherein individuals focus on certain stimuli; (b) excitatory characteristics, stimuli that move between silent stimuli will attract more attention; (c) individual values and needs; (d) previous experience, which greatly influences how someone perceives his world.

In addition, Morgan ${ }^{8}$ explains that true perceptions refer to ways of working, sound, taste, or smell. In other words, perception can be defined as whatever is experienced by someone. Feldman ${ }^{6}$ defines perception as a constructive process in which we receive an existing stimulus and try to understand the situation.

There are three main components of the perception forming process according to Sobur ${ }^{2}$, namely:

a. Selection: the delivery of the senses to external stimuli, the intensity and type can be many or few. After the stimulus is received, it is then selected.

b. Interpretation: the process of organizing information so that it has meaning for someone. Interpretation can be influenced by various factors, such as past experience, a system of values adopted, motivation, personality, and intelligence. Interpretation also depends on a person's ability to categorize information received, namely the process of reducing complex information to be simple.

c. Rounding: drawing conclusions and responses to information received. Perception which is translated in the form of behavior as a reaction is acting in relation to what has been absorbed which consists of hidden reactions as opinions / attitudes, and open reactions as tangible actions in relation to hidden actions (impression formation) ${ }^{2}$.

Based on the description above, it can be concluded that, through the components of perception, namely the selection of information based on the stimulus received by human senses, then the stimulus received will be selected and then interpreted in order to provide conclusions to the object being perceived. Human senses are categorized into five, namely the sense of vision, touch, smell, hearing, and taste.

\section{SENSE OF SAFETY}

The need for a sense of safety must be seen in a broad definition, not limited to physical safety, but also psychological safety. Potter and Perry ${ }^{3}$ argue that safety is a condition free from physical and psychological injury or it can also be safe and secure condition. Craven ${ }^{5}$ explained that safety is something which actually not only prevents pain and injury but also makes individuals feel safe in their activities. Safe is defined in several senses, namely, being free from danger, avoiding things that can hurt or bring damage, and avoiding evil, whereas, safety has a definition as a safe condition to avoid danger or injury, a condition that does not result in danger, or which can guard against the occurrence of an event (which causes insecurity). The Indonesian Language Large Dictionary ${ }^{11}$, also describes that safe has several meanings, namely: free from danger; free from interference; protected or hidden (people cannot take it); does not contain risks; and serene (do not feel afraid or worried).

\section{MINIAPOLIS (CHILDREN'S PLAYROOM OF 23 PASKAL, BANDUNG)}

Miniapolis is a playroom for families with children aged 0-12 years. Miniapolis comes with a special design that can match the imagination of the children's world with a unique choice of games to train the motoric and sensory ability of children. Games in Miniapolis are supported by routine event activities that train children's creativity and imagination.

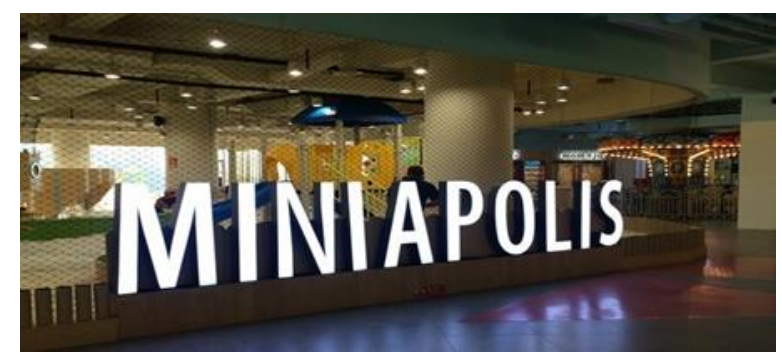

Figure 1. Miniapolis Façade of 23 Paskal

In Indonesia, Miniapolis is present in several shopping centers in big cities, one such family favorite is the Miniapolis of 23 Paskal, Bandung which provides a new playing concept, an outdoor play experience with tame animals, in collaboration with Kampung Gajah, Bandung. There are also indoor and semi-outdoor areas. In a semi-outdoor area, children can feed rabbits or other animals. Not only that, horse-drawn trains and sheep-drawn carriages will also provide exciting memories for young families in Bandung. In the indoor area, the playing area is also quite extensive with all the games that stimulate 
children's rough motoric and fine motoric skills. The area specifically designed for growth of toddlers is given many up and down obstacles that are safe, but quite exciting for children under the age of three. There is a role play area for cooking play, mini supermarkets, and play music is also available for children. There is a train and carousel available for toddlers at the Miniapolis of 23 Paskal. There are also playing excavators for older children to be able to coordinate hands and eyes in operating the tool by moving balls to the basket.

The Miniapolis playground of 23 Paskal, Bandung, was chosen as the object of research because, in this playground, parents are involved as children's companions when playing. It is different from some other playgrounds where companions are not allowed. Thus, in the Miniapolis playground, we can measure to what extent the parents feel safe when accompanying their children to play, because there are often phenomena where parents accompany children to play while doing other activities, such as documenting children or just chatting with fellow parents. However, despite all this, Miniapolis is trying to provide the best for young Indonesian families. The cleanliness, safety, and comfort of each visitor appears well-preferred there. Thus, it will be analyzed as to what extent is the parents' perception of safety in the Miniapolis playground along with their children.

\section{RESULTS}

The questionnaire was given to respondents with the following criteria: parent's gender, children's age, and their visiting frequency to Miniapolis.

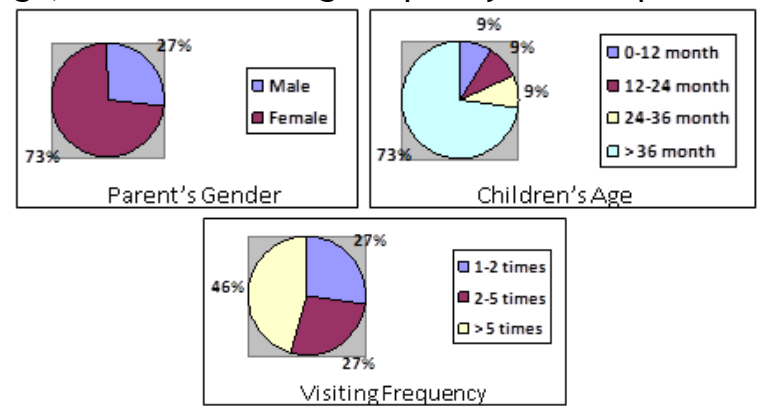

Figure 2. Respondent Profile

Below are the questionnaire results which were reviewed and analyzed as to whether the interior elements that support the safety in the Miniapolis playground relate to users' perception of safety.

\section{EFFECTS OF LIGHT IN PARENTS' PERCEPTION OF SAFETY WHEN CHILDREN PLAY AT THE MINIAPOLIS OF 23 PASKAL, BANDUNG}

Based on a review of lighting theory, a safe indicator will appear if there is a match between the sensory response of the eye to the light captured around the child while playing. The following are lighting indicators as seen from the level of illumination:
1. The level of lighting seen from the front facade toward the Miniapolis playroom

2. Overall lighting inside the Miniapolis playground

3. The level of lighting in the active play area (slides, climbing, jumping, etc.)

4. The level of lighting in the passive game area (reading books, Lego blocks, sandboxes, etc.)

The discussion points above are measured using four lighting level indicators, which are very dim, dim, bright, and very bright. This is not certain to associate the dimness as insecurity or otherwise, so the measurement of perceived safety uses the points discussed above again with the indicators of very unsafe, unsafe, safe, and very safe. The following is the result of the questionnaire analysis of the lighting effect on safe perception using the sense of vision.

Table 1: Lighting Intensity and Sense of Safety from Facade Lighting to Indoor Area

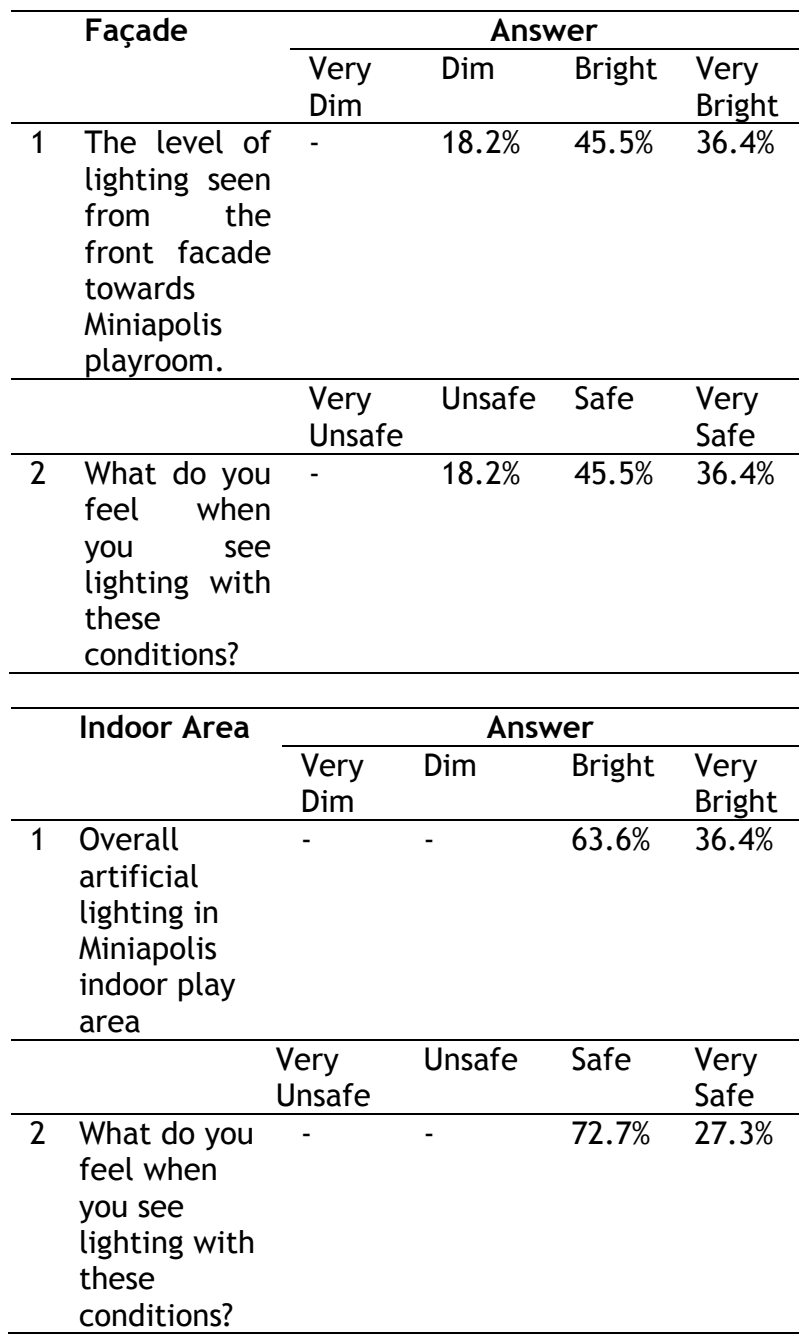

The results of above questions related to the level of illumination of the facade and the parents' perception of safety for lighting are very closely related. It can be concluded that parents will feel safer when they see their children playing in a place that looks bright, from the facade to the indoor area. 
Table 2: Lighting Intensity and Sense of Safety from Semi-Outdoor Area Lighting

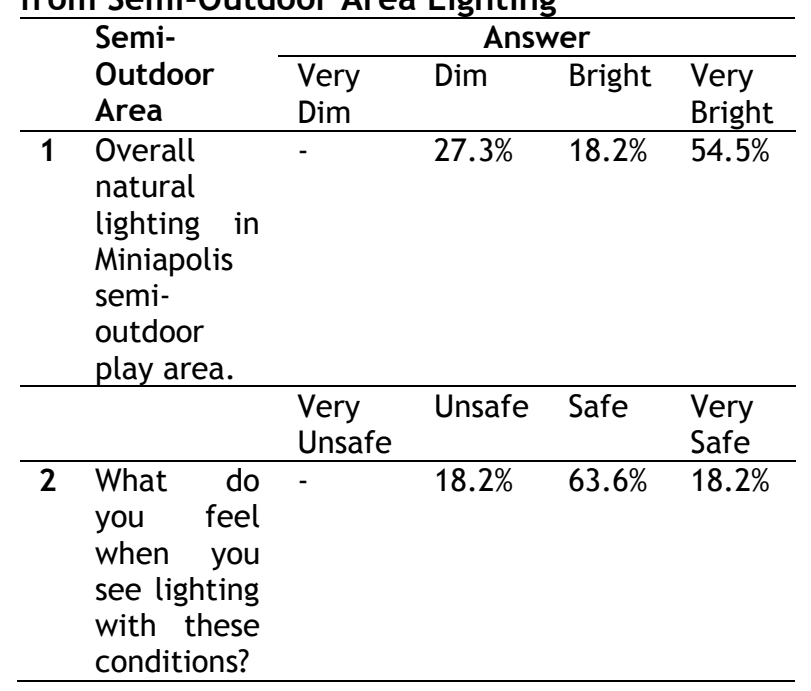

The level of lighting and the parents' perception of safety for natural lighting in a semi-outdoor play area show a slight value difference from that in the indoor area. In this case, natural lighting is considered underexposed or $\operatorname{dim}(27.3 \%)$ to be able to illuminate the semi-outdoor play area. However, it can be analyzed that this dim indicator does not mean parents feel insecure. A sense of safety $(63.6 \%)$ can still be raised even though the lighting tends to be dim. This can happen because the theory says that, actually, natural lighting is a good lighting that can be able to support the child's movement when playing. Natural lighting can also accommodate the supervision needs of parents when accompanying children to play. Based on the connection above, it can be concluded that parents will feel safer when they see their children playing in a place that looks bright or slightly dim, but with lighting that comes from sunlight in a semi-outdoor area.

Table 3: Lighting Intensity and Sense of Safety from Lighting of Active Play Area and Quiet Play Area

\begin{tabular}{|c|c|c|c|c|c|}
\hline & \multirow{2}{*}{$\begin{array}{l}\text { Active Play } \\
\text { Area }\end{array}$} & \multicolumn{4}{|c|}{ Answer } \\
\hline & & $\begin{array}{l}\text { Very } \\
\text { Dim }\end{array}$ & Dim & Bright & $\begin{array}{l}\text { Very } \\
\text { Bright }\end{array}$ \\
\hline \multirow[t]{2}{*}{1} & $\begin{array}{l}\text { The level of } \\
\text { lighting in } \\
\text { the active } \\
\text { play area } \\
\text { (sliding, } \\
\text { climbing, } \\
\text { swing, etc.). }\end{array}$ & - & $\begin{array}{l}9.1 \\
\%\end{array}$ & $72.7 \%$ & $18.2 \%$ \\
\hline & & $\begin{array}{l}\text { Very } \\
\text { Unsafe }\end{array}$ & Unsafe & Safe & $\begin{array}{l}\text { Very } \\
\text { Safe }\end{array}$ \\
\hline 2 & $\begin{array}{l}\text { What do you } \\
\text { feel when } \\
\text { you see } \\
\text { lighting with } \\
\text { these } \\
\text { conditions? }\end{array}$ & - & - & $81.8 \%$ & $18.2 \%$ \\
\hline
\end{tabular}

\begin{tabular}{|c|c|c|c|c|c|}
\hline & \multirow{2}{*}{$\begin{array}{l}\text { Quite Play } \\
\text { Area }\end{array}$} & \multicolumn{4}{|c|}{ Answer } \\
\hline & & $\begin{array}{l}\text { Very } \\
\text { Dim }\end{array}$ & Dim & Bright & $\begin{array}{l}\text { Very } \\
\text { Bright }\end{array}$ \\
\hline \multirow[t]{2}{*}{1} & $\begin{array}{l}\text { The level of } \\
\text { lighting in } \\
\text { the passive } \\
\text { play area } \\
\text { (reading } \\
\text { books, Lego } \\
\text { blocks, } \\
\text { etc.). }\end{array}$ & - & - & $72.7 \%$ & $27.3 \%$ \\
\hline & & $\begin{array}{l}\text { Very } \\
\text { Unsafe }\end{array}$ & Unsafe & Safe & $\begin{array}{l}\text { Very } \\
\text { Safe }\end{array}$ \\
\hline 2 & $\begin{array}{l}\text { What do } \\
\text { you feel } \\
\text { when you } \\
\text { see lighting } \\
\text { with these } \\
\text { conditions? }\end{array}$ & - & - & $72.7 \%$ & $27.3 \%$ \\
\hline
\end{tabular}

Lighting levels and parents' safety perceptions of lighting in active play areas are closely related. Active play area here means the playing area that maximizes the rough motoric role of children, such as sliding, jumping, and so on. According to the results of the questionnaire table above, it can be analyzed that bright indicators for parents certainly meet the indicators of safe perception. Based on the relationship above, it can be concluded that parents with children under five will feel more calm or safe when they see their children playing actively in a place or area that looks bright in the active play section. As with quiet play areas, this area maximizes the sensory role of children, such as reading books, Lego blocks, and so on. Similar to the active play area, it can be concluded that parents will feel more calm or safe when they see their children playing in a place or area that looks bright in the quiet play section.

\section{EFFECT OF SOUNDS ON PARENTS' PERCEPTION OF SAFETY WHEN CHILDREN ARE IN THE MINIAPOLIS PLAYROOM OF 23 PASKAL}

Based on a review of sound theory, a safe indicator will appear if there is a match between the auditory sensory response, which is the ear, to the level of sound volume captured around the child while playing. The following is a sound indicator seen from the level of volume intensity:

1. The volume level of music instruments played in Miniapolis playroom.

2. The sound level of the building's mechanical system (for example: the sound of air conditioning, machinery, pipes, etc.) in the Miniapolis playroom.

3. The level of echo from reflections of children's sounds while playing.

The discussion points above are measured using four hearing level indicators, which are very noisy, noisy, calm, and very calm. As it is uncertain whether noise can be associated with insecurity or otherwise, the perceptions 
measurement of safety are, thus, used again. The point indicators discussed above are very unsafe, unsafe, safe, and very safe. The following is the result of questionnaire analysis about the sounds' effect on safe perception by using the sense of hearing.

Table 4: Volume Intensity and Sense of Safety from the Sounds of Musical Instruments in the Playroom

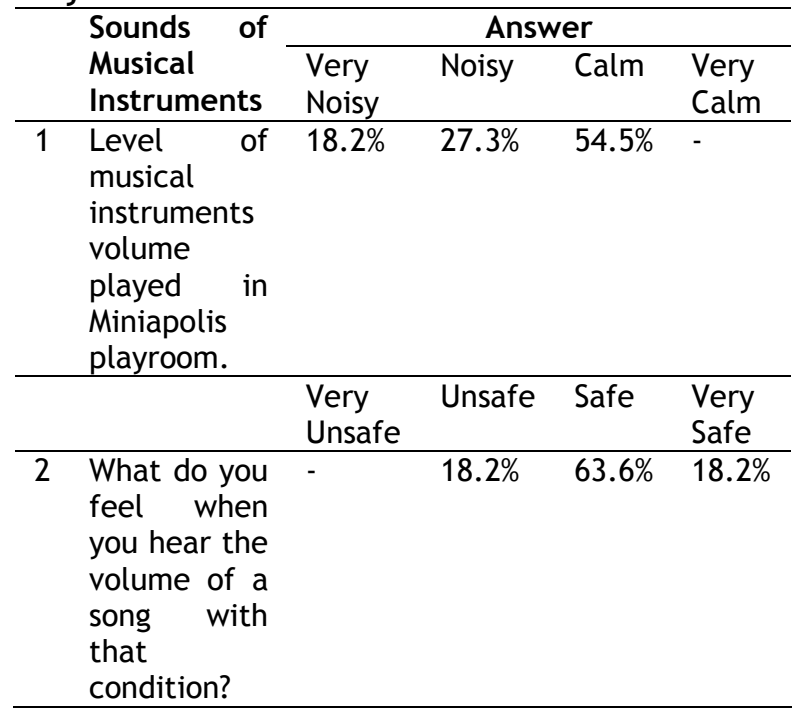

The level of musical instruments volume played in the play area and the parents' perception of safety about it have a slightly different relationship. Although the volume level of the instruments for $45.5 \%$ of respondents was considered quite noisy, $81.8 \%$ of them felt that this was considered safe. Based on the relationship above, it can be concluded that parents feel safe when their children play in a place where the children's songs are heard with quiet enough intensity to accompany them playing.

Table 5: Volume Intensity and Sense of Safety from the Sounds of Mechanical Devices in Indoor Area and Semi-Outdoor Area

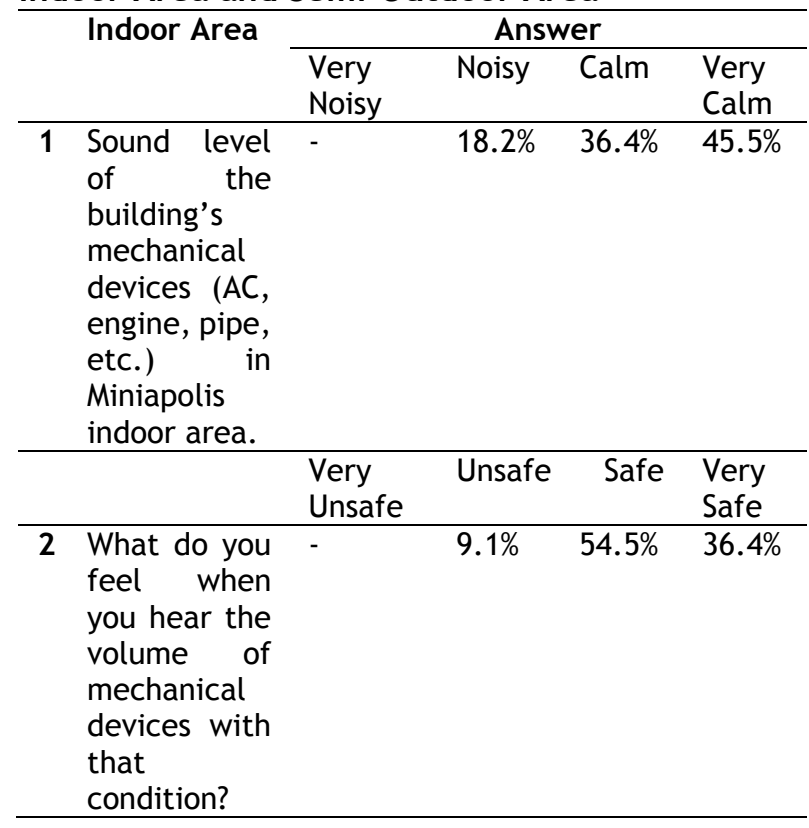

The results of the previous questions relate to the level of volume generated by the building's mechanical devices, both in indoor and semioutdoor playing areas, the parents' perception of safety about mechanical devices volume has the same percentage results. The level of mechanical devices volume for most respondents was considered quite calm, and almost inaudible, but only a small percentage of them felt that this was considered unsafe. Based on the relationship above, it can be concluded that parents feel safe when their children play in a condition where the mechanical devices' sounds are quiet, both in the indoor area and in the semi-outdoor area.

Table 6: Volume Intensity and Sense of Safety from Other Children's Sounds

\begin{tabular}{|c|c|c|c|c|c|}
\hline & \multirow{2}{*}{$\begin{array}{l}\text { Sounds of } \\
\text { Other } \\
\text { Children } \\
\text { Playing }\end{array}$} & \multicolumn{4}{|c|}{ Answer } \\
\hline & & $\begin{array}{l}\text { Very } \\
\text { Noisy }\end{array}$ & Noisy & Calm & $\begin{array}{l}\text { Very } \\
\text { Calm }\end{array}$ \\
\hline \multirow[t]{2}{*}{1} & $\begin{array}{l}\text { The echo } \\
\text { level that } \\
\text { results from } \\
\text { the sound } \\
\text { reflection of } \\
\text { children } \\
\text { playing. }\end{array}$ & - & $45.5 \%$ & $36.4 \%$ & $18.2 \%$ \\
\hline & & $\begin{array}{l}\text { Very } \\
\text { Unsafe }\end{array}$ & Unsafe & Safe & $\begin{array}{l}\text { Very } \\
\text { Safe } \\
\end{array}$ \\
\hline 2 & $\begin{array}{l}\text { What do you } \\
\text { feel when } \\
\text { you hear the } \\
\text { echo sound } \\
\text { of the } \\
\text { children } \\
\text { playing? }\end{array}$ & - & $27.3 \%$ & $45.5 \%$ & $27.3 \%$ \\
\hline
\end{tabular}

Based on the analysis from the table above related to the level of sound volume generated by the echo sounds of children playing in the play area and parents' perception safety about the volume of the children playing, they have a slightly different correlation. The level of echo sound from children playing for most respondents is considered quite noisy, but most of them feel that this is still considered safe. Based on the relationship above, it can be concluded that parents feel uninterrupted by the noise of children playing and still feel safe when watching their children play in a place where there are other children in the playroom.

\section{INFLUENCE OF INTERIOR MATERIAL SURFACES ON PARENTS' PERCEPTION OF SAFETY WHEN CHILDREN PLAY IN THW MINIAPOLIS PLAYROOM OF 23 PASKAL.}

Interior material is one of the important factors that can affect parents' perception of safety when accompanying their children to play. The main interior safety indicator is if the material used contains the value of "softness" or good soft properties. Based on a theoretical review of interior materials in a playroom, a safe indicator will appear if there is a surface of soft material 
around the child while playing. The other indicators that support safety are slippery and not slippery. The following are indicators of floor material seen from soft and slippery level of the properties:

1. Overall floor surface material in the Miniapolis play area.

2. Surface material of the floor in the active play area (slide, climbing, jumping, etc.).

3. Surface material of the floor in the passive play area (reading books, Lego blocks, sandboxes, etc.).

The points of discussion above are measured using four indicators of "softness" level, which are very soft (very safe), soft (safe), hard (unsafe), and very hard (very unsafe). This also certainly can be linked to the slippery level as insecurity or otherwise, so the measure for safety perceptions is defined directly in the points discussed above with indicators very unsafe, unsafe, safe, and very safe. The following is the questionnaire analysis result of floor surface material effect on safe perceptions using the sense of touch.

Table 7: Slippery and Hard Intensity of Floor Surface

\begin{tabular}{|c|c|c|c|c|c|}
\hline & Question & & Answ & & \\
\hline & Indicator & $\begin{array}{l}\text { Very } \\
\text { Slippery }\end{array}$ & Slippery & Rough & $\begin{array}{l}\text { Very } \\
\text { Rough }\end{array}$ \\
\hline 1 & $\begin{array}{l}\text { Overall floor } \\
\text { material } \\
\text { surface in the } \\
\text { Miniapolis } \\
\text { play area. }\end{array}$ & - & $27.3 \%$ & $54.5 \%$ & $18.2 \%$ \\
\hline 2 & $\begin{array}{l}\text { The floor } \\
\text { material } \\
\text { surface in the } \\
\text { active play } \\
\text { area (slides, } \\
\text { climbing, etc) }\end{array}$ & - & $9.1 \%$ & $63.6 \%$ & $27.3 \%$ \\
\hline 3 & $\begin{array}{l}\text { The floor } \\
\text { material } \\
\text { surface in the } \\
\text { passive play } \\
\text { area (reading } \\
\text { books, etc.) }\end{array}$ & - & - & $63.6 \%$ & $36.4 \%$ \\
\hline & & $\begin{array}{l}\text { Very } \\
\text { Hard }\end{array}$ & Hard & Soft & $\begin{array}{l}\text { Very } \\
\text { Soft }\end{array}$ \\
\hline 1 & $\begin{array}{l}\text { Overall floor } \\
\text { material } \\
\text { surface in the } \\
\text { Miniapolis } \\
\text { play area. }\end{array}$ & - & $9.1 \%$ & $81.8 \%$ & $9.1 \%$ \\
\hline 2 & $\begin{array}{l}\text { The floor } \\
\text { material } \\
\text { surface in the } \\
\text { active play } \\
\text { area (slides, } \\
\text { climbing, } \\
\text { etc). }\end{array}$ & - & $18.2 \%$ & $63.6 \%$ & $18.2 \%$ \\
\hline 3 & $\begin{array}{l}\text { The floor } \\
\text { material } \\
\text { surface in the } \\
\text { passive play } \\
\text { area (reading } \\
\text { books, etc.) }\end{array}$ & - & $9.1 \%$ & $72.7 \%$ & $18.2 \%$ \\
\hline
\end{tabular}

Based on the table above, the overall floor surface in the Miniapolis play area is categorized as a safe material because more than $60 \%$ respondents feel that the floor is soft, so it can be concluded that parents feel safe when their children play in the Miniapolis play area.

As for the wall material, the soft and hard indicators are used again. Just like the floor, a safe indicator on the wall is obtained from its surface as to whether it is from a soft material or not. The following is the questionnaire analysis result of the wall surface material effect on safe perception using the sense of touch.

Table 8: Hard Intensity of Wall Surface

\begin{tabular}{|c|c|c|c|c|c|}
\hline & \multirow{2}{*}{$\begin{array}{l}\text { Question } \\
\text { Indicator }\end{array}$} & \multicolumn{4}{|c|}{ Answer } \\
\hline & & $\begin{array}{l}\text { Very } \\
\text { Hard }\end{array}$ & Hard & Soft & $\begin{array}{l}\text { Very } \\
\text { Soft }\end{array}$ \\
\hline 1 & $\begin{array}{l}\text { Overall wall } \\
\text { material } \\
\text { surface in the } \\
\text { Miniapolis } \\
\text { play area. }\end{array}$ & $9.1 \%$ & $36.4 \%$ & $45.5 \%$ & $9.1 \%$ \\
\hline 2 & $\begin{array}{l}\text { The wall } \\
\text { material } \\
\text { surface in the } \\
\text { active play } \\
\text { area (slides, } \\
\text { climbing, } \\
\text { jumping, } \\
\text { etc.) }\end{array}$ & $9.1 \%$ & $36.4 \%$ & $45.5 \%$ & $9.1 \%$ \\
\hline 3 & $\begin{array}{l}\text { The wall } \\
\text { material } \\
\text { surface in the } \\
\text { passive play } \\
\text { area (reading } \\
\text { books, Lego } \\
\text { blocks, etc.) }\end{array}$ & $9.1 \%$ & $27.3 \%$ & $54.5 \%$ & $9.1 \%$ \\
\hline
\end{tabular}

Based on the table, the wall surface in the Miniapolis play area is categorized as a safe material. But the percentage of respondents who feel insecure was still considerable; this happened because some parts of the existing walls of the building were not re-coated, so that the surface was hard. Even so, from the respondents' answers, it can be concluded that most of the walls are soft and they feel safe when their children play in the Miniapolis play area.

\section{DISCUSSION}

The lighting in the Miniapolis Playground of 23 Paskal starts from the facade, indoor play area, semi-outdoor play area, active play area, and quiet play area, which, as a whole, has been able to support parents' perception of safety, even though there are different types of lighting in indoor and semi-outdoor playrooms. In addition, to get natural light reflected from the window, the indoor playroom also gets artificial lighting through fluorescent lighting as the general lighting, so that some people say that the lighting in this area is very bright yet very safe, while the semi-outdoor playroom only gets natural lighting from the sun, but the parents' perception of 
safety is still quite good. If compared with the literature, this happens because sunlight has a CRI level of 100 , where, when there is a dimly lit area, this area still gets enough natural light to support children's play activities. As for the CRI magnitude in the indoor area, it is also very bright from the general light

In terms of sound management, Miniapolis has been quite good at implementing strategies to control noise, especially for sounds coming from building mechanical devices. Even though there are many ducting pipes, air conditioning, and sprinklers in the indoor area, the sound can be well muted using sound-absorbing coatings. Besides that, the musical instruments played as a background music in Miniapolis can also create a pleasant atmosphere as well as a sense of safety for parents and children. Compared with the literature, Miniapolis has been able to apply the kind of sound that is friendly to children's hearing, which are the sounds of soft musical instruments, muted mechanical devices sounds, and minimizing the echo of other children's voices with sound proofing soft material.

Sound is also related to the application of material. As well as a silencer, soft material is also useful to create safety perceptions through the sense of touch. Based on the questionnaire analysis associated with literature, Miniapolis has met the safety standards of floor and wall materials, which are not slippery, and soft, which can also accommodate parents' perception of safety.

\section{CONCLUSION}

The following are the research result conclusions on the application of interior aspects of a playroom which consists of lighting, sounds, and interior material surfaces, which affect the parents' perception of safety when accompanying their children to play in the Miniapolis of 23 Paskal, Bandung:

1. Bright aspects of lighting, soft sound, and soft interior surface material as a standard component of the safety playroom are proven to help create parents' perception of safety when accompanying children to play; therefore, parents can monitor their child from a further distance, and children can freely explore the play area without parents feeling worried.

2. The Miniapolis playroom, as one of the large public playrooms in Bandung, has implemented safety standards in terms of lighting, sounds, and interior material surfaces which are also proven to be able to create parents' perception of safety when watching their children play.
3. The Miniapolis playroom interior can be a reference for other public spaces in the city and outside the city of Bandung to maintain children's safety while playing, as well as make the parents feel safe and not worried.

In terms of sound management, Miniapolis has been quite good at implementing strategies to control noise, especially for sounds coming from building mechanical devices. Even though there are many ducting pipes, air conditioning, and sprinklers in the indoor area, the sound can be well muted using sound-absorbing coatings. Besides that, the musical instruments played as a background music in Miniapolis can also create a pleasant atmosphere as well as a sense of safety for parents and children. Compared with the literature, Miniapolis has been able to apply the kind of sound that is friendly to children's hearing, which are the sounds of soft musical instruments, muted mechanical devices sounds, and minimizing the echo of other children's voices with sound proofing soft material.

Sound is also related to the application of material. As well as a silencer, soft material is also useful to create safety perceptions through the sense of touch. Based on the questionnaire analysis associated with literature, Miniapolis has met the safety standards of floor and wall materials, which are not slippery, and soft, which can also accommodate parents' perception of safety.

\section{ACKNOWLEDGEMENTS}

The authors wish to thank the staff of the interior design department of Telkom University, respondents and the head of PPM Telkom University in providing assistance in this study.

\section{COMPETING INTERESTS}

There is no conflict of interest.

\section{REFERENCES}

1. Abdul Rahman Shaleh and Muhbib Abdul Wahab. Psikologi Suatu Pengantar (Dalam Perspektif Islam). Kencana: Jakarta, (2004).

2. Sobur, A. 2003. Psikologi Umum. Bandung: Pustaka Seti. Djaali. (2007)

3. Potter, A. and Perry, A. G. (2006). Buku Ajar Fundamental Keperawatan: Konsep, Proses, Dan Praktik, Volume2, no 4. Jakarta: EGC. Ardinata. (2007).

4. Chaplin, J.P. Kamus Lengkap Psikologi. Jakarta: PT. Raja Grafindo Persada,(2006). 
5. Craven, R.F. and Hirnle, J. Fundamentals of Nursing. Philadelphia: Lippincott. (2000).

6. Feldman, S. Robert. Understanding Psychology. McGraw Hill College, (1999).

7. Greenman, J. Caring spaces, learning places: Children's environments that work, WA: Exchange Press, Redmond, (1988).

8. Morgan, Myvanway. Social Support and Health. (1987).

9. Olds, R. Anita. Child Care Design Guide, New York. McGraw Hill, (2000).

10. [10] Sarwono and Sarlito Wirawan. Psikologi Umum. Jakarta: Bulan Bintang, (1991). 11. Information on http://
kbbi.kemdikbud.go.id/entri/aman. Accessed January 11th, 2019. 